\title{
The Photo-assimilation of Acetate by Pyrobotrys (Chlamydobotrys) stellata
}

\author{
By K. H. GOULDING AND M. J. MERRETT \\ School of Applied Biology, University of Bradford, Bradford, 7
}

(Accepted for publication 21 February 1967)

\begin{abstract}
SUMMARY
Alcohols, amino acids, organic acids and sugars were tested as carbon sources for the growth of Pyrobotrys (Chlamydobotrys) stellata in the light and dark. Growth was only recorded with acetate in the light. A carbon balance sheet of ${ }^{14} \mathrm{C}$-acetate assimilation showed a greater incorporation of ${ }^{14} \mathrm{C}$ into polysaccharide and less released as ${ }^{14} \mathrm{CO}_{2}$ in the light, compared with the dark. The primary products of ${ }^{14} \mathrm{C}$-acetate assimilation into the soluble fraction of the organisms were identified; after $10 \mathrm{sec} .40 \%$ of the total ${ }^{14} \mathrm{C}$ present in this fraction was in succinic acid, $15 \%$ in citric acid and $16 \%$ in malic acid. The percentage of total ${ }^{14} \mathrm{C}$ in this fraction present in succinic and malic acids decreased consistently with time, while that in citric acid initially increased before decreasing. After $10 \mathrm{sec}$. the specific activity of succinic acid was more than twice that of citric acid. $4 \times 10^{-3} \mathrm{M}$-monofluoroacetate (MFA) effectively inhibited the incorporation of ${ }^{14} \mathrm{C}$-acetate into tricarboxylic acid cycle intermediates and related compounds, and markedly inhibited ${ }^{14} \mathrm{CO}_{2}$ evolution. $10^{-6} \mathrm{M}-N^{1}$-(3-4, dichlorophenyl)- $N, N$-dimethyl urea (DCMU) did not significantly inhibit ${ }^{14} \mathrm{C}$-metabolism. The key enzymes of the glyoxylate cycle, isocitrate lyase (E.C.4.1.3.1) and malate synthetase (E.C.4.1.3.2) were found to be present in $P$. stellata, and did not disappear in the absence of acetate, but even so growth was not recorded on acetate in the dark.
\end{abstract}

\section{INTRODUCTION}

Many algae will utilize acetate as a sole source of carbon for growth (Pringsheim, 1946). The most specialized type of algal acetate nutrition appears to be that shown by Pyrobotrys (Chlamydobotrys) stellata, which can only grow on acetate in the light and was unable to utilize any other carbon source for growth tested by Pringsheim \& Wiessner (1960). The growth of $P$. stellata on acetate appears to differ in several important respects from the growth on acetate of other algae investigated, particularly Chlorella pyrenoidosa (Syrett, Merrett \& Bocks, 1963; Syrett, Bocks \& Merrett, 1964; Goulding \& Merrett, 1966; Merrett \& Goulding, 1967). Chlorella pyrenoidosa can assimilate and grow on acetate in the dark, growth being dependent on the induction of glyoxylate cycle enzymes (Syrett et al. 1963, 1964). Growth in the light is not dependent on the presence of glyoxylate cycle enzymes (Syrett et al. 1963; Goulding \& Merrett, 1966). Unlike $C$. pyrenoidosa the glyoxylate cycle is implicated in the growth of $P$. stellata on acetate in the light (Wiessner \& Kuhl, 1962), but $P$. stellata will not grow on acetate in the dark. Thus, the regulation of the glyoxylate cycle enzymes, isocitrate lyase (E.C.4.1.3.1) and malate synthetase (E.C.4.1.3.2) may be different in $P$. stellata from that in $C$. pyrenoidosa. The aerobic assimilation of 
acetate in the light by $P$. stellata was unaffected by $N^{1}$-(3,4-dichlorophenyl)- $N, N$ dimethyl urea (DCMU) (Wiessner \& Gaffron, 1964) a specific inhibitor of non-cyclic photophosphorylation (Losada \& Arnon, 1963). In C. pyrenoidosa DCMU induced a pattern of acetate assimilation in the light similar to that in the dark (Goulding \& Merrett, 1966). In the presence of DCMU, in the light, less acetate carbon was incorporated into the organisms, particularly into the lipids, polysaccharide and protein, and more was released as carbon dioxide, while isocitrate lyase and malate synthetase, normally repressed in the light, were induced (Goulding \& Merrett, 1966). It would appear that these two algae differ in their enzyme complements and in their dependence on the light reactions of photosynthesis for acetate photo-assimilation. This being so we decided to investigate the products of aerobic acetate photo-assimilalation in $P$. stellata although these have already been described for $C$. pyrenoidosa (Merrett \& Goulding, 1967).

\section{Organism}

METHODS

Pyrobotrys stellata Korschikoff (L 10-1 e) (= Chlamydobotrys stellata) was obtained from the Algensammlung Pflanzenphysiolisches Institut, Göttingen, Germany. The organism was grown in the culture medium of Wiessner (1962), stock cultures being maintained in $20 \mathrm{ml}$. medium contained in cotton-wool plugged tubes kept at room temperature $\left(20^{\circ}\right)$ with a light intensity of 200 lumens/ft. ${ }^{2}$.

Growth. Organisms for experimental use were grown in $125 \mathrm{ml}$. of medium in Dreschel bottles. They were inoculated with organisms from 2-day stock cultures to give a population density of 500-organisms $/ \mathrm{mm}^{3}$. The cultures were grown at $25^{\circ} \pm$ $0.2^{\circ}$ at a light intensity of 300 lumens/ $\mathrm{ft}^{2}$ and air containing $5 \%(\mathrm{v} / \mathrm{v})$ carbon dioxide was bubbled through the cultures at a rate of $41 . / \mathrm{hr}$. After 3 days organisms were harvested by centrifugation at $500 \mathrm{~g}$ for $10 \mathrm{~min}$., washed twice and resuspended in $0.067 \mathrm{M}$-phosphate buffer ( $\mathrm{pH} \mathrm{6.7)}$ to give a concentration equivalent to $8 \mathrm{mg}$. drywt organism $/ \mathrm{ml}$, the concentration being estimated turbidimetrically by the use of an appropriate calibration curve. For kinetic experiments organisms were washed and resuspended in distilled water to give a concentration equivalent of $4 \mathrm{mg}$. dry-wt organism $/ \mathrm{ml}$.

Pyrobotrys stellata normally utilizes acetate as the carbon source for growth in the light; other carbon compounds were tested to see whether they supported growth. Samples of growth medium $(50 \mathrm{ml}$.) lacking acetate were dispensed into $250 \mathrm{ml}$. conical flasks and supplemented with carbohydrate to a final concentration $1 \%(\mathrm{w} / \mathrm{v})$ or alcohols, organic acids or amino acids to a final concentration $0.2 \%(w / v)$. The media were adjusted to $\mathrm{pH} 6 \cdot 5$. The flasks were aseptically inoculated with organisms from stock cultures, the dry weight of the inoculum being estimated directly on separate samples. Cultures were kept in the light (intensity 200 lumens/ft. ${ }^{2}$ ) or in the dark at $25^{\circ}$ for 2 weeks, then the dry weight of organism estimated directly, and the viability determined by inoculating stock culture tubes.

\section{Radiochemical experiments}

Acetate assimilation by Pyrobotrys stellata was followed by using ${ }^{14} \mathrm{C}$-acetate. A suspension of $P$. stellata was equilibrated in the light or dark for $1 \mathrm{hr}$ in the main compartment of large photochemical Warburg Flasks (light intensity 1200 lumens/ft. ${ }^{2}$; 
temperature $25^{\circ}$ ). ${ }^{14} \mathrm{C}$-acetate was then tipped from the side arm. After $1 \mathrm{hr}$ the organisms were killed either by the addition of $10 \mathrm{~N}$-sulphuric acid through the side arm, or samples of suspension were placed in ice-cold centrifuge tubes which were rapidly centrifuged and the deposited organisms killed by immersion of the tubes in boiling water for $2 \mathrm{~min}$. The preparation of fractions from these organisms and the determination of ${ }^{14} \mathrm{C}$ in the fractions was as described previously (Goulding \& Merrett, 1966). ${ }^{14} \mathrm{CO}_{2}$ evolved was absorbed by hydroxide of Hyamine (Packard Inc., Wembley) in detachable centre wells. These were transferred to glass counting-vials containing $10 \mathrm{ml}$. of $0.5 \%$ (w/v) 2,5-diphenyloxazole (PPO) + 0.03\% (w/v) 1,4-bis-2-(4-methyl-5phenyloxazolyl)-benzene (POPOP) in toluene, mixed well and counted in a Tricarb Liquid Scintillation Spectrometer with automatic background subtraction, corrections being made for quenching. The amount of ${ }^{14} \mathrm{C}$-acetate added in experiments was determined by persulphate combustion (Katz, Abraham \& Baker, 1954).

In kinetic experiments $20 \mathrm{ml}$. of suspension containing organism equivalent $80 \mathrm{mg}$. dry-wt in distilled water were transferred to rapid sampling apparatus (Syrett et al. 1964) and maintained at $25^{\circ}$ at a light intensity of 1200 lumens/ft. ${ }^{2}$. After equilibration $30 \mu$ moles sodium acetate were added, followed at zero time by $10 \mu$ moles sodium${ }^{14} \mathrm{C}$-acetate containing $50 \mu \mathrm{c}$. Organisms were sampled at intervals, extracted with ethanol and water, labelled compounds separated by two-dimensional chromatography, located by radio-autography, compounds identified, and ${ }^{14} \mathrm{C}$ in each compound determined, all as described previously (Merrett \& Goulding, 1967).

\section{Preparation of cell-free extracts}

Organisms were washed and resuspended in ice-cold 0.1 M-phosphate buffer $\mathrm{pH} 7 \cdot 5$ and passed through an ice-cold French pressure cell at 15,000 lb./in. ${ }^{2}$ (Milner, Lawrence \& French, 1950). The extract was centrifuged at $500 \mathrm{~g}$ at $2^{\circ}$ for $5 \mathrm{~min}$., followed at $13,000 \mathrm{~g}$ for $20 \mathrm{~min}$., and the supernatant fluid used for enzyme assays. The protein content was estimated by the method of Lowry, Rosebrough, Farr \& Randall (1951), with bovine albumin as a standard.

\section{Enzyme assays}

Isocitrate lyase activity was estimated by the method of Kornberg \& Madsen (1958) usually on cell-free enzyme preparations, but occasionally by using frozen wholeorganism suspensions (Syrett et al. 1963).

Malate synthetase was determined by the method of Syrett et al. (1963).

\section{Organic acids}

Organic acids were eluted from chromatograms and estimated by fluorescence of their resorcinol derivative by the method of Frohman \& Orten (1953). Fluorescence was measured with a Locarte Fluorimeter with LF/3 blue filter, standard calibration curves being prepared for each acid estimated.

\section{RESULTS}

\section{Utilization of carbon compounds for growth}

A wide range of carbon compounds were tested to see whether they supported growth of Pyrobotrys stellata; alcohols, organic acids, amino acids and carbohydrates 
were tested. Of all the compounds tested only acetate supported significant growth in the light. Carbon dioxide and compounds closely related to acetate, such as ethanol, did not support growth. The mean generation time for $P$. stellata growing on acetate in the light at $25^{\circ}$ was $12 \cdot 3 \mathrm{hr}$, while the final yield of organism was $27,750 / \mathrm{mm} .^{3}$.

\section{The assimilation of ${ }^{14} \mathrm{C}$-labelled acetate}

Organisms were equilibrated in Warburg flasks in light or dark, then $10 \mu$ moles ${ }^{14} \mathrm{C}$-acetate containing $2 \mu \mathrm{c}$ were added from the side arm. After metabolism of acetate had ceased (this was longer in the dark than in the light) organisms were sampled and distribution of ${ }^{14} \mathrm{C}$ in the various fractions determined (Table 1). When the organisms metabolized acetate in the dark far more acetate ${ }^{14} \mathrm{C}$ was released as $\mathrm{CO}_{2}$ as compared with metabolism in the light (Table 1). The increased yield of ${ }^{14} \mathrm{CO}_{2}$ in the dark was correlated with the incorporation of less acetate into the acid hydrolysate (polysaccharide + nucleic acids) fraction (Table 1). Although there was some increase in ${ }^{14} \mathrm{C}$ incorporation into the ethanol fraction in the light (Table 1), it was not as great as with Chlorella pyrenoidosa, where the bulk of the acetate carbon is incorporated into lipid in the light (Syrett et al. 1964; Goulding \& Merrett, 1966).

\section{Table 1. The recovery of ${ }^{14} \mathrm{C}$ added as ${ }^{14} \mathrm{C}$-1-acetate or ${ }^{14} \mathrm{C}$-2-acetate to Pyrobotrys stellata in the light and in dark}

For experimental details see materials and methods and text

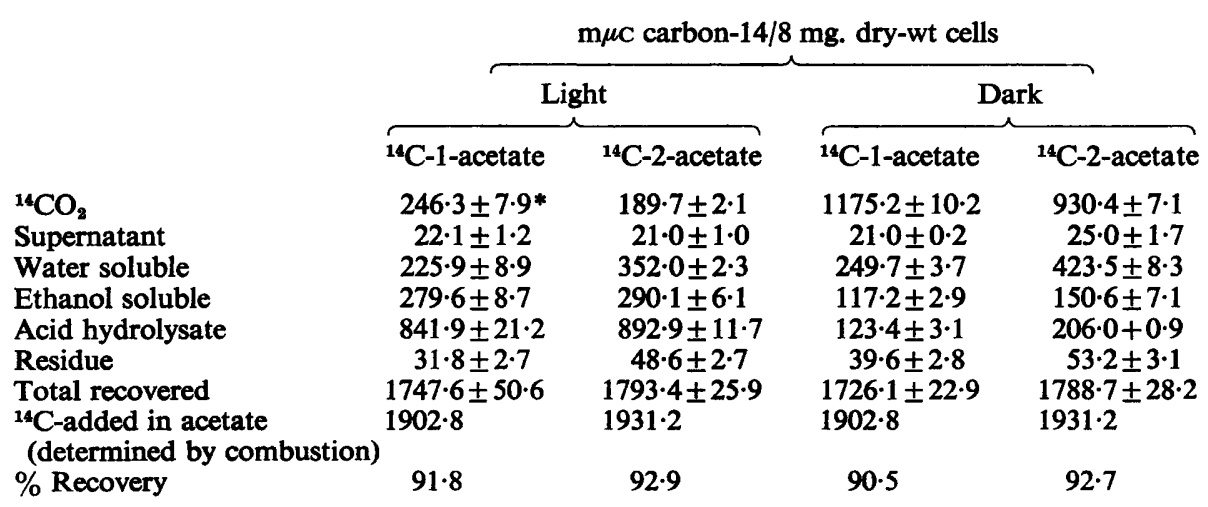

*Figures are the means of duplicate flasks.

\section{Short-term products of ${ }^{14} \mathrm{C}$-2-acetate assimilation}

The results of an experiment investigating ${ }^{14} \mathrm{C}$-2-acetate assimilation in the light are given in Fig. 1. In the earliest sample (10 sec.) $40 \%$ of the ${ }^{14} \mathrm{C}$-2-acetate assimilated into compounds present on the chromatogram was in succinic acid, $15 \%$ in citric acid and $16 \%$ in malic acid. The percentage of total ${ }^{14} \mathrm{C}$ on the chromatogram in succinic and malic acids decreased consistently with time, while there was a slight increase in the percentage of the total ${ }^{14} \mathrm{C}$ present in citric acid before a decrease (Fig. 1). The total counts/min. present in succinic acid was greater than that in citric acid and so was the specific activity (Table 2). Glutamic acid rapidly incorporated ${ }^{14} \mathrm{C}$ from ${ }^{14} \mathrm{C}$-2-acetate, while aspartic acid, serine, glycine, alanine, glutamine and 
threonine became labelled in later samples but not to the same extent as glutamic acid (Fig. 1).

A compound found in an investigation of ${ }^{14} \mathrm{C}$-acetate assimilation by Chlorella pyrenoidosa, at present unidentified and recorded as compound $X$ by Merrett \& Goulding (1967), was also found in Pyrobotrys stellata, where it accounted for $8.4 \%$ of total ${ }^{14} \mathrm{C}$ assimilated after $1800 \mathrm{sec}$. Glucose was the major product of acetate assimilation after $1800 \mathrm{sec}$. and contained $19 \%$ of the total ${ }^{14} \mathrm{C}$ (Fig. 1).

Table 2. The specific activity of acids of the tricarboxylic cycle during ${ }^{14} \mathrm{C}$-2-acetate assimilation by Pyrobotrys stellata in the light

\begin{tabular}{|c|c|c|c|c|c|c|c|c|c|}
\hline \multirow{3}{*}{$\begin{array}{l}\text { Time of } \\
\text { sampling } \\
\text { from } \\
\text { addition of } \\
{ }^{4} \text { C-acetate } \\
\text { (sec.) }\end{array}$} & \multicolumn{9}{|c|}{ For experimental conditions see legend to Fig. 1.} \\
\hline & \multicolumn{3}{|c|}{ Counts/min incorporated } & \multicolumn{3}{|c|}{$\begin{array}{l}\text { Concentration of acid } \\
\mathrm{m} \mu \mathrm{mole} / 7 \cdot 2 \mathrm{mg} \cdot \mathrm{dry}-\mathrm{wt}\end{array}$} & \multicolumn{3}{|c|}{$\begin{array}{l}\text { Specific activity } \\
\text { m } \mu \mathrm{c} / \mu \text { mole acid }\end{array}$} \\
\hline & $\begin{array}{l}\text { Suc- } \\
\text { cinic }\end{array}$ & Citric & Malic & $\begin{array}{l}\text { Suc- } \\
\text { cinic }\end{array}$ & Citric & Malic & $\begin{array}{l}\text { Suc- } \\
\text { cinic }\end{array}$ & Citric & Malic \\
\hline $\begin{array}{r}10 \\
30 \\
60 \\
120 \\
300 \\
1800\end{array}$ & $\begin{array}{l}1927 \\
2398 \\
2460 \\
2508 \\
2980 \\
2879\end{array}$ & $\begin{array}{r}721 \\
1136 \\
1544 \\
1747 \\
2593 \\
2625\end{array}$ & $\begin{array}{l}1002 \\
1254 \\
1270 \\
1527 \\
3386\end{array}$ & $\begin{array}{l}71 \cdot 2 \\
72 \cdot 9 \\
73 \cdot 7 \\
76 \cdot 3 \\
83 \cdot 1 \\
86 \cdot 4\end{array}$ & $\begin{array}{l}63 \cdot 5 \\
67 \cdot 7 \\
65 \cdot 6 \\
68 \cdot 8 \\
70 \cdot 3 \\
71 \cdot 9\end{array}$ & $\begin{array}{l}62 \cdot 9 \\
62 \cdot 9 \\
64 \cdot 5 \\
66 \cdot 1 \\
66 \cdot 1\end{array}$ & $\begin{array}{l}148.9 \\
181 \cdot 0 \\
183 \cdot 1 \\
180 \cdot 8 \\
197 \cdot 3 \\
182.8\end{array}$ & $\begin{array}{r}62.9 \\
91 \cdot 5 \\
129 \cdot 5 \\
139.5 \\
201.9 \\
200 \cdot 2\end{array}$ & $\begin{array}{r}87 \cdot 4 \\
109 \cdot 6 \\
108.5 \\
127 \cdot 0 \\
281 \cdot 3\end{array}$ \\
\hline
\end{tabular}

Table 3. The effect of monofluoroacetate (MFA) on ${ }^{14} \mathrm{C}$-acetate metabolism by Pyrobotrys stellata in the light

Organisms were incubated in the light for $60 \mathrm{~min}$., some in the presence of $4 \times 10^{-8} \mathrm{M}-\mathrm{MFA}$ : $80 \mu$ moles ${ }^{14} \mathrm{C}-1$-acetate containing $2 \mu \mathrm{C}$ were added and after $1 \mathrm{hr}$ organisms were sampled and fractionated as in Methods. Values given are means of duplicate flasks.

\begin{tabular}{lcc} 
& \multicolumn{2}{c}{$\mathrm{m} \mu \mathrm{c}^{14} \mathrm{C} / 8 \mathrm{mg}$. dry-wt organisms } \\
\cline { 2 - 3 } Control $^{14} \mathrm{CO}_{2}$ evolved & 42.1 & $4 \times 10^{-8} \mathrm{M}-\mathrm{MFA}$ \\
Supernatant fluid & 7.8 & 2.4 \\
Water soluble & 14.1 & 11.3 \\
Ethanol soluble & 8.1 & 4.3 \\
Acid hydrolysate & 16.8 & 2.9 \\
Residue & 1.6 & 2.4 \\
Total & 90.5 & 0.6 \\
\end{tabular}

\section{The effect of inhibitors on the photoassimilation of acetate}

The effect of monofluoroacetate (MFA). The addition of MFA may result in the accumulation of fluorocitrate and the inhibition of aconitase (Treble, Lamport \& Peters, 1962) and also the inhibition of malate synthetase (Dixon, Kornberg \& Lund, 1960). Thus, MFA inhibits respiration proceeding by the tricarboxylic acid cycle and the glyoxylate by-pass. The effect of MFA on acetate metabolism by Pyrobotrys stellata was investigated by incubating organisms with MFA for 60 min., then adding ${ }^{14} \mathrm{C}$-acetate and sampling the organisms after a further $60 \mathrm{~min}$. (Table 3). Inhibition of ${ }^{14} \mathrm{C}$-2-acetate incorporation into the ethanol, water-soluble fraction and acid-hydrolysate fraction was particularly marked, and ${ }^{14} \mathrm{CO}_{2}$ evolution was decreased to a very low value. 
The effect of MFA was also investigated by determining the rate of incorporation of ${ }^{14} \mathrm{C}$-2-acetate into the soluble fraction of the organisms. After $10 \mathrm{sec}$. the pattern of acetate assimilation was similar to that found in the absence of the inhibitor except that glutamic acid was not labelled; after $10 \mathrm{sec}$. the total counts incorporated increased only slightly throughout the rest of the experiment (Fig. 2). The incorporation of ${ }^{14} \mathrm{C}$ into succinic, citric and malic acids was strongly inhibited, while other compounds labelled in the absence of the inhibitor (Fig. 1) did not incorporate ${ }^{14} \mathrm{C}$ in detectable amounts (Fig. 2).

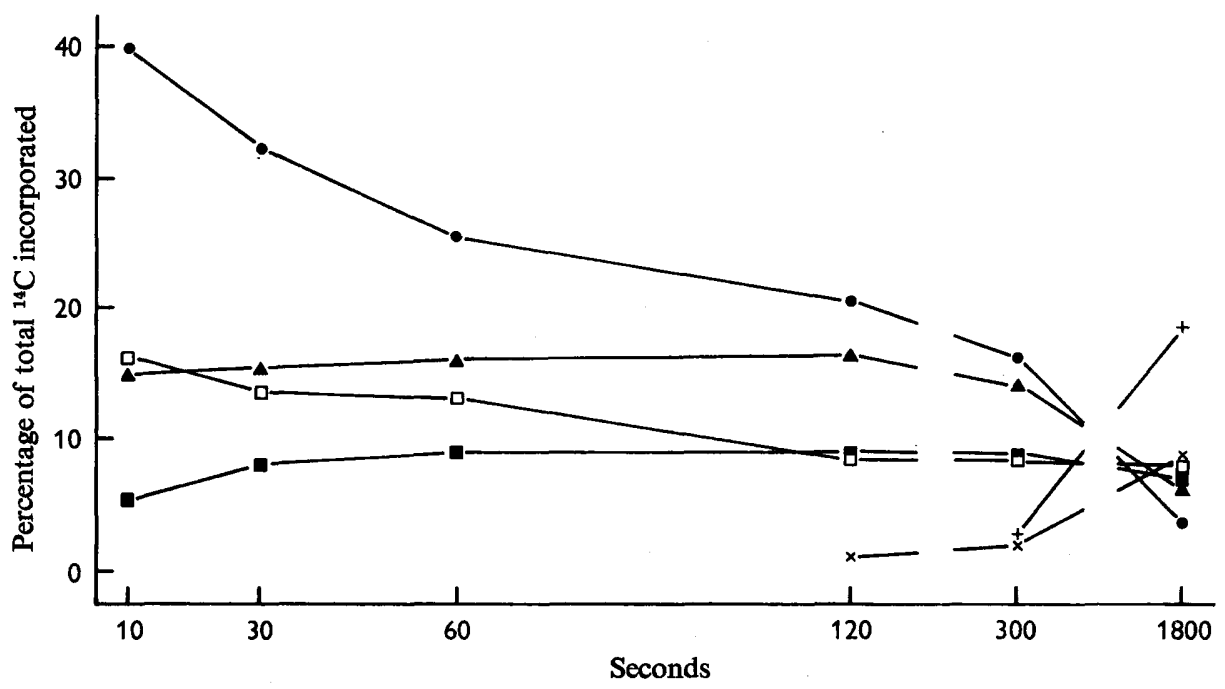

Fig. 1. Short-term products of ${ }^{14} \mathrm{C}-2$-acetate assimilation in the light by Pyrobotrys stellata. Twenty $\mathrm{ml}$. of organism suspension (equivalent $4 \mathrm{mg}$. dry-wt/ml.) were transferred to sampling apparatus, aerated and allowed to equilibrate in the light for $1 \mathrm{hr}: 30 \mu$ moles sodium acetate were added $10 \mathrm{~min}$. before zero time, followed at zero time by $10 \mu \mathrm{moles}$ ${ }^{14} \mathrm{C}-2$-acetate containing $50 \mu \mathrm{c}$. Organisms sampled, extracted and chromatographed and ${ }^{14} \mathrm{C}$ determined as in methods. Percentage ${ }^{14} \mathrm{C}$ in any one compound expressed as percentage of total ${ }^{14} \mathrm{C}$ present on the chromatogram. - , Succinate; $\square$, malate; $\boldsymbol{\Lambda}$, citrate; $\mathbf{v}$, glutamate; $\times$, compound $X ;+$, glucose.

Effect of $N^{1}$-(3,4-dichlorophenyl)- $N, N$-dimethyl urea (DCMU). DCMU is a powerful inhibitor of photosynthesis, inhibiting the generation of $\mathrm{NADPH}_{2}$ and ATP by noncyclic photo-phosphorylation (Losada \& Arnon, 1963). Wiessner \& Gaffron (1964) found that DCMU was without effect on aerobic acetate assimilation in the light by Pyrobotrys stellata, while Goulding \& Merrett (1966) found that DCMU induced a dark pattern of acetate metabolism in the light in Chlorella pyrenoidosa, resulting in decreased lipid and polysaccharide formation and increased release of ${ }^{14} \mathrm{CO}_{2}$. The effect of DCMU on ${ }^{14} \mathrm{C}$-2-acetate incorporation into various cell fractions of $P$. stellata (Table 4) confirmed the observation of Wiessner \& Gaffron (1964) that acetate assimilation was unaffected by DCMU, and also showed that ${ }^{14} \mathrm{C}$-2-acetate incorporation into other cell fractions was also unaffected by DCMU (Table 4). 
Glyoxylate cycle enzymes in Pyrobotrys stellata

The nature of control of glyoxylate cycle enzymes in Pyrobotrys stellata has not hitherto been investigated. $P$. stellata organisms grown on acetate in the light were centrifuged down aseptically, resuspended in fresh medium and aerated in the presence of acetate in the dark, and in the light without acetate. The presence or absence of
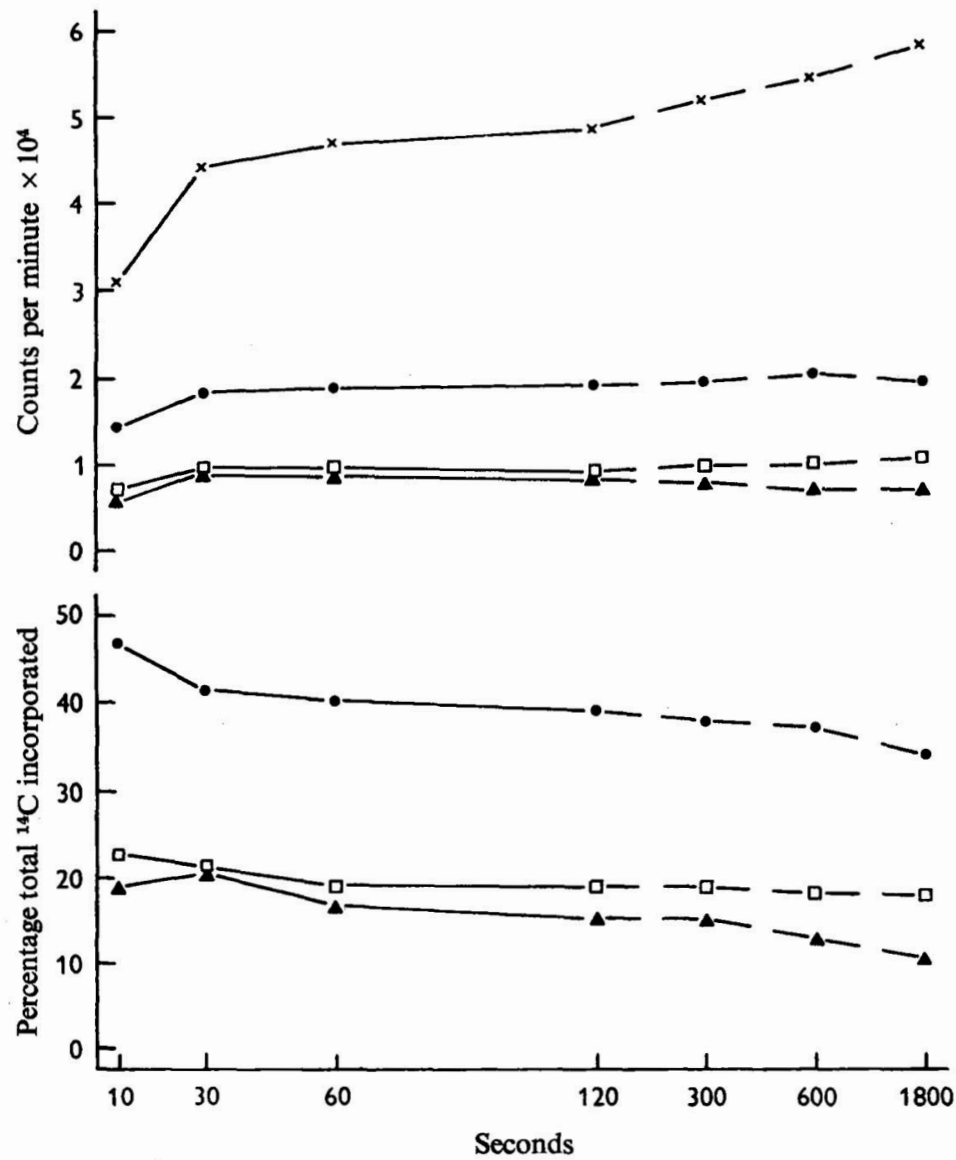

Fig. 2. Short-term products of ${ }^{14} \mathrm{C}$-2-acetate assimilation by Pyrobotrys stellata in the light in the presence of $4 \times 10^{-3} \mathrm{M}$-MFA. Twenty ml. of organism suspension (equiv. $4 \mathrm{mg}$. dry-wt/ ml.) were transferred to sampling apparatus, aerated and allowed to equilibrate in the light for $1 \mathrm{hr}$ in the presence of MFA to give final concentration $4 \times 10^{-3} \mathrm{M}: 30 \mu$ moles sodium acetate were added $10 \mathrm{~min}$. before zero time, followed at zero time by $10 \mu$ moles ${ }^{14} \mathrm{C}$-2-acetate containing $50 \mu \mathrm{c}$. Organisms sampled, extracted and chromatographed and ${ }^{14} \mathrm{C}$ determined as in methods. (a) Total counts min. per compound: $\times-\times$, total counts $/ \mathrm{min}$. incorporated. (b) Percentage ${ }^{14} \mathrm{C}$ in any one compound expressed as percentage of total ${ }^{14} \mathrm{C}$ present on the chromatogram. 0 , Succinate; $\boldsymbol{\Delta}$, citrate; $\square$, malate.

$\mathrm{CO}_{2}$ had no effect on the amounts of enzyme in the organisms. The results of these experiments (Fig. 3) suggest that malate synthetase and isocitrate lyase are constitutive in $P$. stellata but we were unable to test this experimentally because the organism will 
not grow on any carbon source except acetate. Despite this, growth on acetate in the dark did not take place (as it does in Chlorella pyrenoidosa where these enzymes are induced when organisms are incubated with acetate in the dark; Syrett et al. 1963).

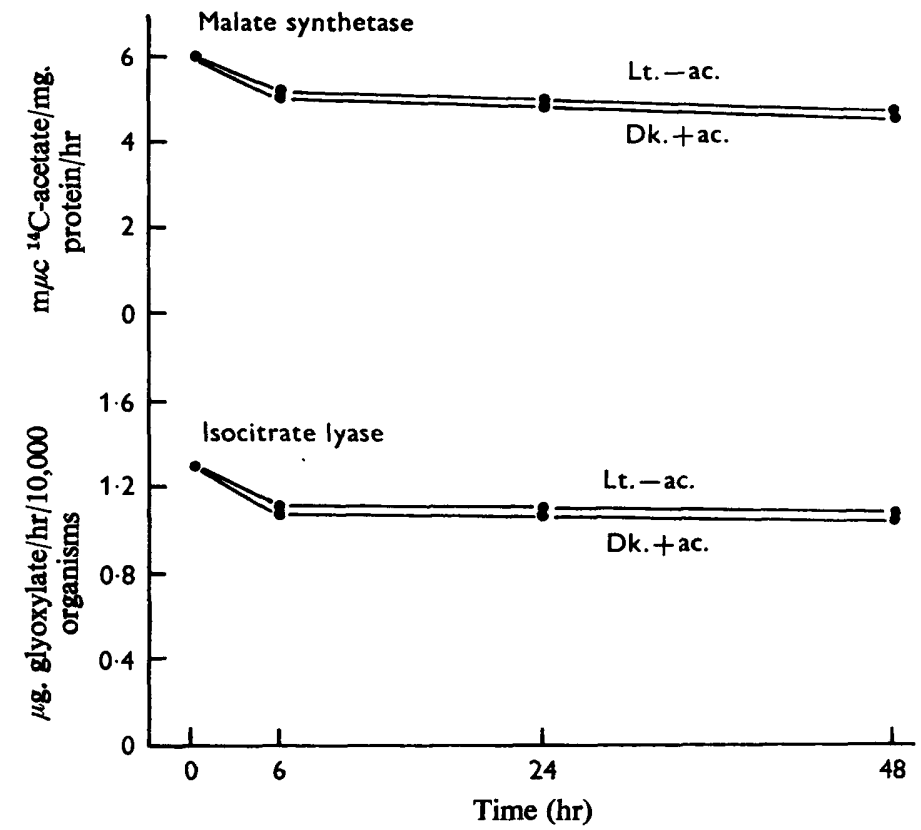

Fig. 3. Malate synthetase and isocitrate lyase in Probotrys stellata. Organisms were grown on acetate in the light, harvested aseptically and resuspended. (a) In acetate-free medium and incubated in the light; $(b)$ in acetate-containing medium and incubated in the dark. Samples of organisms were removed at zero time and after 6, 24 and $48 \mathrm{hr}$ incubation and assayed for enzyme activity.

Table 4. The effect of $10^{-6} M-D C M U$ on ${ }^{14} C$-1-acetate assimilation by Pyrobotrys stellata in the light

Organisms were allowed to equilibrate in the light in presence or absence of DCMU at time $0,80 \mu$ moles ${ }^{14} \mathrm{C}$-1-acetate containing $2 \mu \mathrm{C}$ added. Organisms sampled after $1 \mathrm{hr}$ and fractionated, as in Methods.

${ }^{14} \mathrm{CO}_{2}$ evolved
Supernatant
Water extract
Ethanol extract
Acid hydrolysate
Cell residue
Total

${ }^{14} \mathrm{CO}_{2}$ evolved

Ethanol extract

Cell residue

Total $\mathrm{m} \mu \mathrm{C}{ }^{14} \mathrm{C} / 8 \mathrm{mg}$. dry wt. organisms

\begin{tabular}{cc}
\hline Control & $10^{-6}$ M-DCMU \\
54.7 & 69.6 \\
5.8 & 4.1 \\
14.8 & 13.5 \\
8.6 & 7.3 \\
11.0 & 10.8 \\
0.6 & 1.0 \\
95.5 & 106.3
\end{tabular}

\section{DISCUSSION}

The incorporation of ${ }^{14} \mathrm{C}$-acetate into the soluble fraction of the cells of Pyrobotrys stellata resembles ${ }^{14} \mathrm{C}$-acetate assimilation in Chlorella pyrenoidosa in that succinate becomes rapidly labelled with ${ }^{14} \mathrm{C}$ (Merrett \& Goulding, 1967). After $10 \mathrm{sec}$. over $40 \%$ 
of the ${ }^{14} \mathrm{C}$ present in the $P$. stellata organisms was in succinic acid while only $15 \%$ is in citric acid (Fig. 1). This result cannot be explained on the basis of a larger pool size of succinic acid trapping more ${ }^{14} \mathrm{C}$ passing through the tricarboxylic acid cycle, since initially the specific activity of succinic acid was greater than that of citric acid (Table 2). Moreover, in a kinetic-type experiment (as in Fig. 1) initially the greatest percentage of the total ${ }^{14} \mathrm{C}$ assimilated was in the primary products, and this decreased with time as ${ }^{14} \mathrm{C}$ enters other compounds. In several experiments we always obtained the result recorded in Fig. 1, where the slope of the graph for succinic and malic acids is decreasing while that of citric acid is increasing in the early samples. Cell-free extracts of $P$. stellata showed isocitrate lyase and malate synthetase activity and, assuming that these enzymes were functioning in the intact organism in the light, succinic acid could be formed from the breakdown of isocitric acid by isocitrate lyase. However, if succinic acid is formed in this manner it is difficult to see how the specific activity of succinate can be greater than that of citrate from which it was derived via isocitrate. The rapid increase in the specific activity of malic acid (Table 2) supports the view that malate synthetase was active in the intact $\boldsymbol{P}$. stellata organisms, and malic acid was being formed from acetyl-CoA and glyoxylate. There was no evidence of malic formation from carboxylation reactions to this extent; ${ }^{14} \mathrm{CO}_{2}$ incorporation into the organisms was only $10 \%$ of carbon- 14 incorporation from ${ }^{14} \mathrm{C}$-acetate. It also seems unlikely that succinate could be formed via malic acid, because initially the specific activity of succinate was greater than that of malic acid (Table 2). Monofluoroacetate effectively inhibited the incorporation of ${ }^{14} \mathrm{C}$-acetate into tricarboxylic acid intermediates (Fig. 2) and blocked ${ }^{14} \mathrm{CO}_{2}$ evolution (Table 3). Furthermore, the total counts of radioactivity incorporated did not increase greatly during the experiment. Citrate did not accumulate and the formation of succinate was inhibited (Fig. 2). This was not so in C. pyrenoidosa when metabolizing ${ }^{14} \mathrm{C}-2$-acetate in the light in the presence of MFA, where citrate did accumulate (Merrett \& Goulding, 1967), and succinate formation was unaffected. It would appear that monofluoroacetate inhibits the uptake of acetate by $P$. stellata, which may indicate that this reaction is dependent on ATP formation resulting from respiration of some of the added acetate.

The effect of DCMU upon acetate assimilation in Pyrobotrys stellata was insignificant (Table 4) as compared with its effect on acetate assimilation in Chlorella pyrenoidosa where it stimulates ${ }^{14} \mathrm{CO}_{2}$ evolution sixfold (Goulding \& Merrett, 1966). Thus, it appears that the role of light in acetate assimilation by $P$. stellata and by $C$. pyrenoidosa is somewhat different. Recent work on the two light reactions of photosynthesis has led to the majority view that they function in series in which the shorter wave system (system II) forms a strong oxidant leading to $\mathrm{O}_{2}$ evolution, while the far red system (system I) forms a strong reductant that reduces NADP (Duysens, Amesz \& Kamp, 1961; Hill \& Bendall, 1960; Witt, Muller \& Rumberg, 1961; Kok 1961). The photoassimilation of acetate by $C$. pyrenoidosa is dependent on system II and if this is blocked by DCMU, reversion to a dark metabolism of acetate occurs (Goulding \& Merrett, 1966). Thus, it seems that an assimilation in light dependent on system I is not possible. $P$. stellata is a weak evolver of oxygen during photosynthesis and it seems probable that system II is deficient in it, while inhibitor experiments with DCMU confirm that acetate assimilation is dependent on system I. In contrast, under anaerobic conditions Wiessner \& Gaffron (1964) found DCMU inhibits the photo- 
assimilation of acetate in $P$. stellata, implying that under these conditions system II is functioning and may not be completely deficient. Wiessner (1965) showed the quantum requirement for acetate assimilation in far red light by $P$. stellata to be 8 . System $\mathrm{I}$ is concerned with $\mathrm{CO}_{2}$ reduction in higher plant photosynthesis, and it seems probable that $P$. stellata is unable to use this system for $\mathrm{CO}_{2}$ reduction because of the absence of ribulose-1-5-diphosphate carboxylase from the organism (Merrett, 1967).

M.J.M. acknowledges the receipt of a special research grant from the Science Research Council in support of the work; K.H. G. was in receipt of a research studentship from the Science Research Council.

\section{REFERENCES}

Dixon, G. H., Kornberg, H. L. \& Lund, P. (1960). Purification and properties of malate synthetase. Biochim. biophys. Acta 41, 217.

Duysens, L. N. M., Amesz, J. \& Kamp, B. M. (1961). Two photochemical systems in photosynthesis. Nature, Lond. 190, 510.

Frohman, C. E. \& ORTEN, J. M. (1953). The fluorimetric determination of polycarboxylic acids following chromatography. J. biol. Chem. 205, 717.

Goulding, K. H. \& MerRETT, M. J. (1966). The photometabolism of acetate by Chlorella pyrenoidosa. J. exp. Bot. 17, 678.

Hill, R. \& BeNDALl, F. (1960). Function of the two cytochrome components in chloroplasts: a working hypothesis. Nature, Lond. 186, 135.

Katz, J., Abraham, S. \& Baker, N. (1954). Analytical procedures using a combined combustiondiffusion vessel. Improved method of combustion of organic compounds in aqueous solution. Analyt. Chem. 26, 1503.

KoK, B. (1961). Partial purification and determination of oxidation reduction potential and the photosynthetic chlorophyll complex absorbing at $700 \mu$. Biochim. biophys. Acta 48, 527.

KorNBERG, H. L. \& MADSEN, N. B. (1958). The metabolism of $\mathrm{C}_{2}$ compounds in micro-organisms. 3. Synthesis of malate from acetate via the glyoxylate cycle. Biochem. J. 68, 549.

Losada, M. \& ARNon, D. I. (1963). Selective inhibitors of photosynthesis. In Metabolic Inhibitors. Ed. by R. M. Hochester and J. H. Quastel, vol. 2, p. 559. New York and London: Academic Press.

Lowry, O. H., Rosebrough, N. J., Farr, A. L. \& Randall, R. J. (1951). Protein measurements by Folin phenol reagent. J. biol. Chem. 193, 265.

Merrett, M. J. (1967). Carbon dioxide fixation in Pyrobotrys stellata. Br. phycol. Bull. (in the Press).

Merrett, M. J. \& Goulding, K. H. (1967). Short-term products of ${ }^{14} \mathrm{C}$-acetate assimilation by Chlorella pyrenoidosa in the light. J. exp. Bot. (In the Press.)

Milner, H. W., LAWrence, N. S. \& French, C.S. (1950). Colloidal dispersion of chloroplast material. Science, N.Y. 111, 633.

Pringsheim, E. G. (1946). Pure Cultures of Algae. Cambridge University Press.

Pringsheim, E. G. \& Wiessner, W. (1960). Photoassimilation of acetate by green organisms. Nature, Lond. 188, 919.

Syrett, P. J., Bocks, S. M. \& Merrett, M. J. (1964). The assimilation of acetate by Chlorella vulgaris. J. exp. Bot. $15,35$.

Syrett, P. J., Merret, M. J. \& Bocks, S. M. (1963). Enzymes of the glyoxylate cycle in Chlorella vulgaris. J. exp. Bot. 14, 249.

Treble, D. H., Lamport, D. T. A. \& Peters, R. A. (1962). The inhibition of plant aconitate hydratase (aconitase) by fluorocitrate. Biochem. J. 85, 113.

WIESSNER, W. (1962). Kohlenstoffassimilation von Chlamydobotrys (Volvocales). Arch. Mikrobiol. 43, 402.

WIESSNER, W. (1965). Quantum requirement for acetate assimilation and its significance for quantum measurements in photophosphorylation. Nature, Lond. 205, 56.

WIESSNER, W. \& GAFFRON, H. (1964). Role of photosynthesis in light-induced assimilation of acetate by Chlamydobotrys. Nature, Lond. 201, 725.

WiessNER, W. \& KUHL, A. (1962). Die Bedeutung des Glyoxylsäurezykbus für die Photoassimilation von Acetat bei phototrophen Algen. Vortr. Ges. Geb. Bot. 1, 102.

Witt, H. T., Muller, A. \& RumBerg, B. (1961). Experimental evidence for the mechanism of photosynthesis. Nature, Lond. 191, 194. 